\title{
More Power to the People: Electricity Adoption, Technological Change, and Labor Conflict
}

\author{
Jakob Molinder, Tobias Karlsson, and Kerstin Enflo
}

Will technical change spur conflicts in the labor market? In this study, we examine electricity adoption in Sweden during the first decades of the twentieth century. Exploiting that proximity to hydropowered plants shaped the electricity network independently of previous local conditions, we estimate the impact of electricity on labor strikes. Our results indicate that electricity adoption preceded an increase in conflicts, but strikes were of an offensive nature and most common in sectors with increasing labor demand. This suggests that electrification provided workers with a stronger bargaining position from which they could voice their claims.

$\mathrm{T}$ oday, there is a wide-spread concern that technical change may spur social conflicts, especially if workers are replaced with mechanized alternatives. Empirical evidence suggests that middle-class or mediumskilled workers have been the most vulnerable to job loss during the last decades (Goos and Manning 2007; Autor, Katz, and Kearney 2006). A recent study even warns that 48 percent of the American workforce could be replaced by computers within a few decades or so (Frey and Osborne 2017). Some scholars have suggested that "technological anxiety" is channeled through the political system and manifested in increasing support for right-wing populism (Dal Bo et al. 2017; Frey, Berger, and Chen 2017).

The Journal of Economic History, Vol. 81, No. 2 (June 2021). C The Economic History Association. doi: 10.1017/S0022050721000127. This is an Open Access article, distributed under the terms of the Creative Commons Attribution license (http://creativecommons.org/ licenses/by/4.0/), which permits unrestricted reuse, distribution, and reproduction in any medium, provided the original work is properly cited.

Jakob Molinder is Postdoctoral Researcher, Department of Economic History, Lund University, Lund, Sweden and Department of Economic History, Uppsala University, Uppsala, Sweden. E-mail: jakob.molinder@ekhist.uu.se. Tobias Karlsson is Associate Professor, Department of Economic History, Lund University, Lund, Sweden. E-mail: tobias.karlsson@ekh.lu.se. Kerstin Enflo is Professor, Department of Economic History, Lund University, Lund, Sweden. E-mail: kerstin.enflo@ekh.lu.se (corresponding author).

We thank the seminar participants at the Centre for Economic History at Queen's University Belfast, the Department of History, Economics and Society at the University of Geneva, the Department of Economic History at Lund, and the Department of Economic History at the University of Helsinki. We are also thankful to the participants at the Social Science History Association Annual Meeting in Phoenix, Arizona and the European Historical Economic Society conference in Paris. Financial support from the Swedish Research Council (project number 20141491), the Wallenberg foundation (KAW2014.0138), and Länsförsäkringars forskningsfond (P2/17) is gratefully acknowledged. 
Given the potentially large societal impact inherent in the introduction of new technology, we might expect potential losers to try to use nonmarket means to hinder the adoption of new technology (Mokyr 1992; Mokyr, Vickers, and Ziebarth 2015). Historically, these non-market means have had different expressions. The most well-known examples are probably the Luddite uprising and the Captain Swing Riots in the wake of the First Industrial Revolution. While it is easy to be caught by the dramatic and colorful stories of machine breaking, the question is how representative anti-machine protests have been in the overall spectrum of workers' responses to technological change. Technological change may also put some categories of workers in a better bargaining position. These potential winners have the opportunity to use non-market means to improve their jobs and wages. When assessing the societal impact of technological change, these "offensive" protests are easily disregarded, since they are rarely explicitly linked to machines.

In this study, we analyze the relationship between technological change and social protests in early twentieth century Sweden. More precisely, we study the adoption of electricity and how it influenced labor conflicts in the form of local strikes in 2,470 parishes. During the Second Industrial Revolution, electricity was a cornerstone in driving mechanization and new ways of organizing production. Yet, the Second Industrial Revolution is less associated with machine breaking compared to the First Industrial Revolution, perhaps because it resulted in an increasing supply of quality jobs, as suggested recently by Frey (2019). It is also possible that increased unionization during the period drove more organized responses to changes on the labor market.

Lacking domestic coal deposits, Sweden experienced an early and influential shock from electrification from the late nineteenth century onward. This development was mainly driven by the expansion of hydroelectric power that gradually overtook steam as the primary source of electricity. ${ }^{1}$ Chronologically, electrification coincided with a documented increase in labor conflicts that made Sweden one of the most strike-prone countries in the industrialized world (Shorter and Tilly 1974). These circumstances, however, are rarely connected in the literature.

Our analysis proceeds in two steps. First, we establish the impact of the adoption of electricity on strikes in local labor markets. We separate strikes based on "offensive" claims (higher wages, shorter working hours, etc.) from strikes associated with more "defensive" claims (against

\footnotetext{
${ }^{1}$ The share of electricity derived from hydro increased from 32 percent to 73 percent between 1890 and 1920 (Kander 2002).
} 
job losses, wage decreases, etc.) Second, we explore the mechanisms behind the conflicts by providing evidence regarding labor demand and structural change. By analyzing structural and occupational change in electricity-adopting parishes, our study connects strike activity with the winners and losers of technological change.

Data on the frequency of strikes are measured at the parish level and have been drawn from a recently geo-coded and digitized dataset on work stoppages in Sweden. The sources give detailed descriptions about the location and the claimed cause of the conflict. ${ }^{2}$ Information on the occupational structure of each parish is based on full-count census data from IPUMS International (Minnesota Population Center 2019). Access to the electricity grid is obtained by digitizing contemporary survey maps. To control for the potential endogeneity of the adoption of electricity, with respect to conflicts and labor demand, we exploit the fact that the connection of two large hydropowered plants shaped the layout of the electricity grid in a way that was independent of pre-existing local characteristics. $^{3}$

Our results speak primarily to the debate about technological change and labor unrest. In historical research, this debate has mainly concerned pre-industrial societies and the empirical difficulties of distinguishing between contemporary rhetoric and more fundamental causes. Mokyr, Vickers, and Ziebarth (2015), for example, suggests that the Luddite Riots, in fact, may have been driven by a "multitude of causes," not only mechanization. When it comes to strikes and the form of labor unrest that is most prevalent in industrial societies, technological change has rarely been the main focus of research, as observed by Franzosi (1989). This observation also applies to recent studies on strike behavior in economic history (see, for example, Card and Olson 1995; Huberman and Young 2002; Geraghty and Wiseman 2011; Houpt and Cagigal 2014).

While we study industrial unrest, we draw inspiration from a study of pre-industrial protests. Caprettini and Voth (2020) have convincingly shown that technological change really was at the root of the unrest associated with the Captain Swing riots in 1830s England. By exploiting instrumental variable techniques, they establish a causal link from the

\footnotetext{
${ }^{2}$ See Enflo and Karlsson (2019) and Molinder, Enflo, and Karlsson (2018). The dataset is stored at the Swedish National Data Service as SND:1088 (https://snd.gu.se/en/catalogue/study/ snd1088), from where it can be obtained upon request.

${ }^{3}$ The argument exploits a combination of two arguments previously used in the literature. First, that exogenous hydroelectric potential determines location of hydropowered plants (Leknes and Modalsli 2020; Gaggl et al. 2019) and, secondly, that the potential costs of distributing electricity are strongly correlated to the distance of the existing electricity grid (Kitchens and Fishback 2015; Lewis and Severnini 2020).
} 
adoption of new threshing machines to social unrest in local communities. We build on their insights by initially seeking to establish a causal link from new technology to protests and then by showing how context mattered in determining who would go on strike. While Caprettini and Voth (2020) find that protests were amplified where workers were impoverished or had few alternative employment opportunities, our study finds that conflicts following electrification were offensive rather than defensive and were particularly frequent in sectors with increasing demand for labor. Contrary to the rebellions driven by "technological anxiety" observed in the nineteenth century, we argue that the strikes in early twentieth-century Sweden were manifestations of workers' improved bargaining positions due to new labor market conditions.

Our results also contribute to the literature on the effects of electricity adoption on structural change and the demand for labor. Previous studies of early electrification have varying results. On the one hand, studies on rural areas in the United States have generally found an increased demand for labor following electrification, a rise in agricultural productivity leading farmers to seek employment off the farm less often (Kitchens and Fishback 2015), as well as short-run agricultural specialization (Kline and Moretti 2013; Lewis and Severnini 2020). In terms of structural change, a recent evaluation finds that electrification explained roughly 18 percent of the decline in the employment share of farmers between 1910 and 1940 in the United States (Gaggl et al. 2019). Similarly, a study from Norway documents a modest increase in the demand for labor following electrification and finds that structural change drove workers away from agriculture and toward non-agricultural activities (Leknes and Modalsli 2020). Our results indicate that labor demand increased in the parishes that adopted electricity early but that jobs were mainly created for low- to medium-skilled workers. Similarly to Leknes and Modalsli (2020) and Gaggl et al. (2019), we find that electricity drove structural change into non-agricultural sectors, a pattern that contrasts studies of early rural electrification in the United States by Kline and Moretti (2013), Lewis and Severnini (2020), and Kitchens and Fishback (2015) that instead document gains in agriculture.

Finally, we contribute to the debate about electricity's impact on the distribution of skills. Again, there is a lack of consensus in the existing literature. Goldin and Katz (1998) famously argued that the Second Industrial Revolution was associated with an increased demand for skilled labor, supported by recent evidence from Norway (Leknes and Modalsli 2020). ${ }^{4}$

\footnotetext{
${ }^{4}$ Prado and Theodoridis (2017) present results in the same direction for Sweden, but of smaller magnitude.
} 
Yet, Gray (2013) finds that the skill structure was "hollowed out" since the demand for white-collar and unskilled jobs increased while the demand for semi-skilled work decreased. We find employment growth in mediumskilled occupations, a pattern of "hollowing in" or occupational upgrading, rather than "hollowing out."

The rest of this paper is organized as follows. The second section lays out the conceptual framework and reviews the historical literature on Swedish labor relations, explaining how we think about electricity adoption as an exogenous impulse to local technological change, its impact on the demand for labor, and subsequent protests in the form of strikes. The third section explains the empirical strategy and data. The fourth section presents the results. The fifth section provides conclusions.

\section{HISTORICAL BACKGROUND AND CONCEPTUAL FRAMEWORK}

The arrival of electricity was a technological shock with revolutionary social and economic consequences. Theoretically, such a change is likely to have caused labor conflicts as existing jobs, institutions, and work practices were challenged. Whether technological change actually translates into more conflicts depends on how the opportunities are divided and whether they influence the relative bargaining power between workers and employers. Workers whose jobs are about to disappear might have reasons to protest but will have poor prospects to launch successful strikes. Workers whose jobs are in greater demand have better prospects to win strikes as they can use new technology "as a vehicle to negotiate improvement" (Drago and Wooden 1990, p. 35). Moreover, as suggested by Perrone (1984), technological change may enhance the ability of some workers' to disrupt processes of production, not only within firms but also more generally in the economy. While Perrone originally applied the idea of positional power to post-industrial societies with well-developed supply chains, it may also be relevant for the context of Sweden in the Second Industrial Revolution. ${ }^{5}$

In the following section, we first explain how the state-led expansion of the electricity network constituted an exogenous local shock to the incentive to adopt the new technology. Thereafter, we discuss how network access influenced firms and labor demand. Finally, we discuss patterns of conflict in the Swedish labor market before summarizing the implications of our empirical findings.

\footnotetext{
${ }^{5}$ Hamark (2013) has, however, applied this perspective when discussing the militancy of dock workers in the first half of the twentieth century.
} 


\section{Electrification and the State-Led Expansion of the Power Grid}

Electrification for motive purposes, that is, to drive machines and appliances, began slowly in the late nineteenth century and accelerated in the first decades of the twentieth century, when different parts of the country became connected to the power grid. ${ }^{6}$ Although private businesses were active in developing and building an infrastructure for the transmission of electricity, the Swedish state took a key role already in the early twentieth century.

With the three-phase alternating current system for transmitting power by electrical grids, it became feasible to take advantage of the large Swedish rivers that ran from the mountains in the north down to the eastern coast and the lakes in the south. The Swedish state was the first in the world to become involved in the commercial operation of power plants (Stymne 2002, p. 10). A public company, The Royal Waterfall Board (Kungliga Vattenfallsstyrelsen), was set up with the purpose of exploiting water power for the generation of electricity. The power plants were operated by a central authority rather than by separate units, and their location came to play a key role in the expansion of the national system. Because local and regional networks suffered from seasonal variations in electricity generation, the state had the ambition early on to create a national network of electricity distribution. The coordinated actions of the state stand much in contrast to the disjointed initiatives taken by individual firms and municipalities to electrify certain locations, as shown in Stymne (2002).

The rapid expansion of the network is striking: in 1906, less than 5 percent of parishes were connected to a grid; by 1916, the number had increased to more than 40 percent. The state accelerated the expansion of the grid and determined much of its shape through the construction of three plants for hydropower generation. The first plant, Olidan, began generating electricity for users throughout western Sweden in 1908. By 1911, the grid had expanded, and the area surrounding the Olidan power plant experienced a significant increase in access. By 1916, the state built two additional plants: Älvkarleby in the east and Porjus in the north. Olidan, Älvkarleby, and Porjus were the biggest power plants of their time and gave The Royal Waterfall Board a leading role as the giant of the business.

The locations for the state-run hydroplants were first selected due to the availability of large waterfalls and second due to their strategic

\footnotetext{
${ }^{6}$ With regard to lighting, Sweden was largely electrified already by the turn of the twentieth century (Hjulström 1940).
} 
location in a network intended to cover the entire country, as explained in Stymne (2002, p. 9). ${ }^{7}$ Olidan was the most powerful source of energy in the country. After three expansions, it had a total capacity of $100 \mathrm{MW}$. In order to equalize production and transfer surplus energy to the parts of the system that had the highest demand, there was an explicit plan to connect Olidan to the second largest plant, Älvkarleby, from the start of the century. The resulting connecting grid became the first cornerstone in a strategic electricity network called "the electric mainline system." While this mainline system was planned to have four lines crossing the country, the first and foremost priority was the Western Line (Centralblocket) between Olidan and Älvkarleby, which was finalized in 1921.

As a result of the differences in the natural endowments for large-water power plant construction, some regions got an early advantage in energy provision simply by being located between the two plants. These regions were, just like Sweden in general, largely rural and relatively backward in terms of industrialization. It is, therefore, reasonable to regard the connection to the state-sponsored electricity grid as providing an exogenous impulse for technical change in certain locations. We will show more formally in the data and empirical strategy section that parishes connected to the Western Line grid can be considered as a suitable treatment group when testing the impact of electricity adoption in relation to a control group covering the rest of the country.

\section{Effects on Firms and Labor Demand}

The economic motives to invest in the new technology when connected to the grid were strong. From the perspective of owners of firms or farms, access to the electricity grid provided a reliable and powerful source of electrical power. Before the grid, many industries could potentially connect to a local water-power source to generate electricity. There is, however, wide-spread evidence that local water power sources were unreliable and often seasonal. The lack of water power was especially prevalent in many local waterfalls during the summer months. Surveys that were carried out among firms at the beginning of the twentieth century reveal the problems. The instability or absence of energy supplies was stated as one main reason why firms could not expand production or

Olidan was selected on the basis of its great water power resources, while Älvkarleby was selected for topographical reasons and for its potential to supply surrounding towns with electricity. Its relative closeness to the capital city, Stockholm, was also considered an advantage, but the city had actually already built its own power plant at Untra, just a few kilometers away. Porjus was selected to supply the iron ore mines and railroads in the far north of Sweden with electricity and to create the basis for new industries in the region. 
modernize their machine park (Hjulström 1940, p. 266). This point is interesting for our purpose since it suggests that continuity in production became increasingly important for employers. Access to the electricity grid allowed firms to invest in more capital-intensive technologies. At the same time, such investments would also make them more vulnerable to disruptions in the form of strikes.

The potential of electricity is manifested in the fact that firms and farms closer to the power grid were more electrified than those further away. ASEA (1912) details the farms that had installed electrical equipment for running the farm at the time of its publication. The list clearly indicates that estates located near the Olidan power plant made heavier use of electrical equipment. Morell (2001), likewise, reports that the construction of the Älvkarleby plant explains why farms were electrified to a greater extent in the Uppland region, where the plant was located.

Electric motors had become relatively affordable by the early twentieth century. The cost of a motor with three horsepower would amount to some 420 SEK, less than half of the average yearly income for a business owner in manufacturing or three-fourths for a business owner in agriculture. The cost of a motor was also less than the alternative cost, the average yearly wage for an unskilled worker. ${ }^{8}$ Such a motor could perform the most common tasks around farms and rural industrial plants. They were often installed in wheeled containers, which made them portable and suitable for multiple purposes (ASEA 1912, pp. 14-27).

In the late nineteenth and early twentieth centuries, industrialization, urbanization, market integration, and economic growth more generally, meant an increased demand for workers in manufacturing, construction, and transportation (Schön 2012). The specific impact on labor demand of electrification differed across sectors and branches. In agriculture, electrification had the clear potential for making unskilled jobs redundant (Morell 2001). If the farm moved directly from manual labor to machines in the processes of threshing, cleaning, and crushing, the laborsaving effect was radical. Even in the rare cases when many operations had already been mechanized through the use of steam and hand power, electric motors could still save on labor. The labor-saving potential was more substantial at large farms, where most of the work was performed by hired laborers, compared to at yeoman farms, where the family of the owner made up the majority of the labor force.

\footnotetext{
${ }^{8}$ These calculations are based on the 140 SEK per horsepower around 1906-1907 cited in Ljungberg (1990), average incomes from Edvinsson (2005), and wages from the Historical Labour Database (HILD) at Göteborgs universitet (https:/www.gu.se/en/school-business-economics-law/ economy-society/the-historical-labour-database-hild).
} 
Outside agriculture, electrification stimulated mechanization and may have given rise to new products and occupations, as well as influencing the pattern of the location of enterprises, thus freeing them from their previous geographic constraints. In the late 1930s, a government inquiry (Rationaliseringsutredningen 1939, p. 37) established that "firms have become less dependent on proximity to previously used energy sources [and that] small-scale industry has been able to emerge in locations which previously had lacked the opportunities for manufacturing activities." In contrast to agriculture, employment in manufacturing, transport, and other services grew substantially in the first half of the twentieth century.

Firms in mechanical engineering were among the early adopters of electricity (Norgren 1992). Here, electrification meant a gradual replacement of previous systems for transmitting power. Ultimately, each machine was either connected to or integrated with an electric motor (Devine 1983). In some firms, such as Munktells in Eskilstuna, this transition was basically completed already in the late 1910s (Magnusson 1987). The decreased reliance on a single power source meant that the physical layout of the shop floor could be more flexible (Magnusson 1987). Machines no longer had to be placed along central shafts. Shop floors became less crowded and brighter as machines were removed from windows. Electricity also facilitated transport within factories, using cranes and traverses.

Along with changes in the organization of production and general expansion, the relative demand for different kinds of occupations also changed. Referring to Swedish mechanical engineering generally, Olsson (1979) observes that the share of non-skilled workers increased. Machine workers and laborers increased in relative numbers, whereas craft workers decreased. Magnusson (1987) argues that an overall expansion of production brought about "more material to handle, more spaces to clean, more products to wrap and unpack."

\section{Labor Market Organizations and Conflicts}

In the latter half of the nineteenth century, riots and spontaneous popular protests, typically performed in times of distress, gave way to organized strikes (Karlbom 1967; Cederqvist 1980). In contrast to the pre-industrial pattern of social conflict, strikes were pro-cyclical and more organized (Mikkelsen 1992). Unionization began in the 1870s in some occupations, and union density grew rapidly to about 17 percent in the early twentieth century, a comparatively high level internationally (Åmark 1986). There were, however, great differences in union density between occupations and sectors. 
Farm laborers have generally been considered as hard to organize (Kjellberg 1983). Swedish farm laborers did not form a lasting national union until 1918 (Back 1961). ${ }^{9}$ In contrast, metal workers were the backbone of the Swedish labor movement for a good part of the twentieth century, achieving a union density of 50 percent already around 1900 (Elmquist 1901). The Swedish Metal Workers' Union formed the model for other unions when achieving a collective agreement with national coverage in 1905 (Lundh 2020). The same union also set a pattern for others in its adoption of industrial unionism, in contrast to earlier unions that were based on craft membership (Åmark 1998). ${ }^{10}$

While technological change, in a broad sense, has been a central theme for Swedish labor historians (Berggren 1991; Magnusson 1987), they have not systematically investigated the relationship between electrification and labor conflicts. We believe that such a study is highly motivated given the rapid expansion of the electricity grid during the period, the strong motives of firms to adopt the new source of energy, and the likely consequences, for the content and availability of jobs. While we expect to see an overall positive impact of electrification on the strike frequency, we hypothesize a diverse impact, depending on the nature of the strike claims and economic sector. To what extent electrification caused more conflicts by threatening jobs or by enhancing the bargaining position of workers is an open question.

\section{DATA AND EMPIRICAL STRATEGY}

To analyze the impact of electrification on strikes, we construct a panel dataset based on 2,470 parishes at unchanging historical borders combining data from three sources (Molinder, Karlsson, and Enflo 2020).

First, our main outcome variable, strikes, comes from Enflo and Karlsson (2019) and includes information on the place of the conflict, the cause of the dispute, as well as the industry that the striking workers

\footnotetext{
${ }^{9}$ Yet farm laborers did leave some imprint in the strike records well before successful unionization, most notably with a series of conflicts in Southern and Middle Sweden 1890-1891, and later in 1906-1908 and in 1918-1922 (Johansson 2008). The claimed causes of discontent documented in the official statistics that covered these latter episodes often concerned wages or simply "better working conditions" (Karlsson 2019).

${ }^{10}$ Swedish employers formed organizations of their own to meet the challenge of the trade unions (Swenson 2002). Although the main Swedish employers' organization came to accept collective bargaining relatively early, industrial conflicts surged in the period around 1890 to 1920 (with a pause during WWI). Some Swedish employers tried to break unions by hiring replacement workers from abroad. As elsewhere, such attempts could lead to violence (Fishback 1995). The use of strikebreakers was halted after the bombing of a ship with British laborers in Malmö in 1908.
} 
TABLE 1

NUMBER OF STRIKES AND STRIKES BY CAUSE

\begin{tabular}{|c|c|c|c|c|c|}
\hline \multirow[b]{3}{*}{ Year } & \multirow{3}{*}{$\begin{array}{l}\text { (1) } \\
\text { Total }\end{array}$} & \multicolumn{4}{|c|}{ Cause: Percent of Total } \\
\hline & & (2) & (3) & (4) & $(5)$ \\
\hline & & Offensive & Defensive & Union Recognition & Other \\
\hline $1891-1896$ & 252 & 44 & 15 & 2 & 40 \\
\hline 1896-1900 & 616 & 38 & 10 & 4 & 47 \\
\hline $1901-1905$ & 803 & 37 & 15 & 4 & 44 \\
\hline 1906-1910 & 1,118 & 40 & 15 & 2 & 43 \\
\hline $1911-1915$ & 528 & 51 & 15 & 1 & 34 \\
\hline $1916-1920$ & 2,336 & 66 & 7 & 0 & 26 \\
\hline
\end{tabular}

Notes: This table shows the number of strikes and the share of strikes by cause between 1891 and 1920. An offensive strike is defined as a conflict over wage increases; defensive strikes are all conflicts caused by wage decreases or layoffs. "Other" includes strikes over collective agreements, hours, personal issues, as well as those with multiple and other causes.

Sources: Enflo and Karlsson (2019), Karlsson (2019), and Swedish National Data Service, SND 1088.

belonged to. All strike data was coded by the sector of economic activity. ${ }^{11}$ We assign geographical coordinates to every location where there was a strike.

Table 1 summarizes all strikes in Sweden, categorized by subperiod and cause. As shown in the table, a majority of the strikes concerned offensive claims, whereas defensive claims were much less common. Strikes for union recognition can only be discerned in a small minority of cases, whereas strikes for "other" causes were frequent but became less common in the two latter subperiods. In the table and in the remainder of the analysis, we distinguish between offensive and defensive strikes. We define these two categories narrowly, where the former mainly concerns demands for wage increases and the latter concerns protests against wage cuts or layoffs. This leaves us with a relatively small category of strikes for union recognition and a relatively big category of "other" causes. In the "other" category, we include conflicts concerning collective agreements, hours, personal issues, as well as those with multiple and other causes. Most of these events would probably have been classified as

${ }^{11}$ An important event to bear in mind when reading Table 1 is the General Strike of 1909 (Schiller 1967). This conflict began as a lockout initiated by the Swedish Confederation of Employers (SAF) but spread as the Confederation of Blue-Collar Workers (LO) launched a strike. The number of workers involved came to exceed 300,000. The workers lost the showdown, and many unions were weakened for years to come, explaining the comparably low frequency of strikes in the period 1911-1915 seen in Table 1. It should also be noted that the use of violence is a dimension that is not included in Swedish statistics on work stoppages and thus not shown in Table 1 . 
"offensive" if we had applied a broader definition. In Table A7 of Online Appendix B, we show that our results are robust to the inclusion of strikes for other causes in the offensive category. ${ }^{12}$

Second, to measure the potential mechanisms from electricity to strikes, we collect data on the occupational structure of each parish by aggregating census information on the number of persons involved in different activities. The digitized census from The Swedish National Archives, Umeå University, and the Minnesota Population Center (2011a, 2011b, 2012) was used for this. Unfortunately, these data were only available for 1890,1900 , and 1910, so the scope of the analysis concerning the employment structure is limited to those years. The occupations recorded in the census are assigned to different categories of skill, using the HISCLASS class scheme. This is a system that divides historical occupations into 12 categories, ranging from elite to unskilled farm workers. To make the interpretation of our results easier, we use an abbreviated version of HISCLASS, with only seven groups. ${ }^{13}$ The HISCLASS scheme and our aggregate categories are described in greater detail in Online Appendix C.

It would have been useful to assign the occupations to the main economic sectors, but we are, unfortunately, limited to the information embedded in the occupational titles in the censuses, where it is not possible to distinguish activities in manufacturing from those carried out in services. ${ }^{14}$ It is, however, much more straightforward to distinguish agricultural occupations from the other economic sectors. Thus, we are able to look at shifts in labor demand from agriculture to the rest of the economy. This is a useful distinction since agriculture remained the largest sector in the Swedish economy until the 1930s, and a shift from agriculture to other sectors suggests that a structural change was taking place.

Third, for electricity adoption, digitized survey maps of the Swedish electricity grid in 1906, 1911, and 1916 provided by the Swedish National Archive, Riksarkivet, give us a spatially coded dataset for the geographical location of all power lines in existence. Figure 1 depicts how the shape of the electricity grid was determined by the location of the three state-run hydropower plants and their openings. Due to the exogenous nature of

\footnotetext{
${ }^{12}$ Interestingly enough, when looking through all the strike causes, conflicts with the openly declared intention to resist mechanization were extremely rare. In our dataset, we are only able to identify two strikes that could fall under the cause of blocking technological change.

${ }^{13}$ These are: "1. Elite," "2. White collar," "3. Foremen," "4. Medium skilled," "5. Farmers," "6. Low skilled," and "7. Unskilled."

${ }^{14}$ This is in contrast to the Norwegian census used by Leknes and Modalsli (2020), which provides information on both the occupational titles and the economic sectors. These data show that, outside of agriculture, there is a significant overlap of occupations and sectors, making it exceedingly difficult to infer the economic sector from the occupational title in the Swedish census.
} 


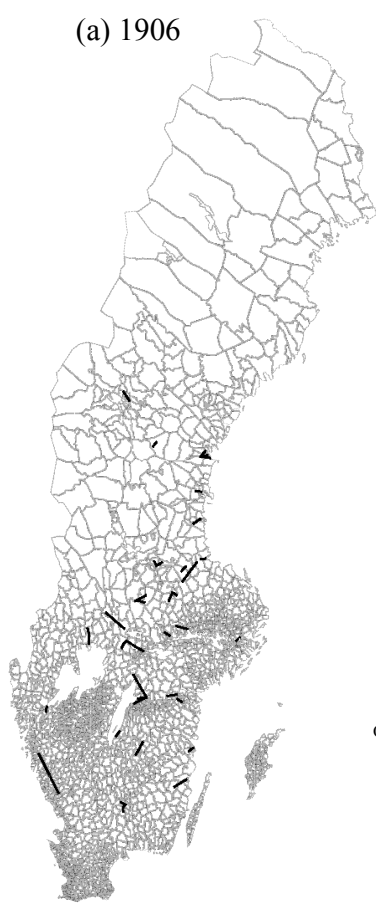

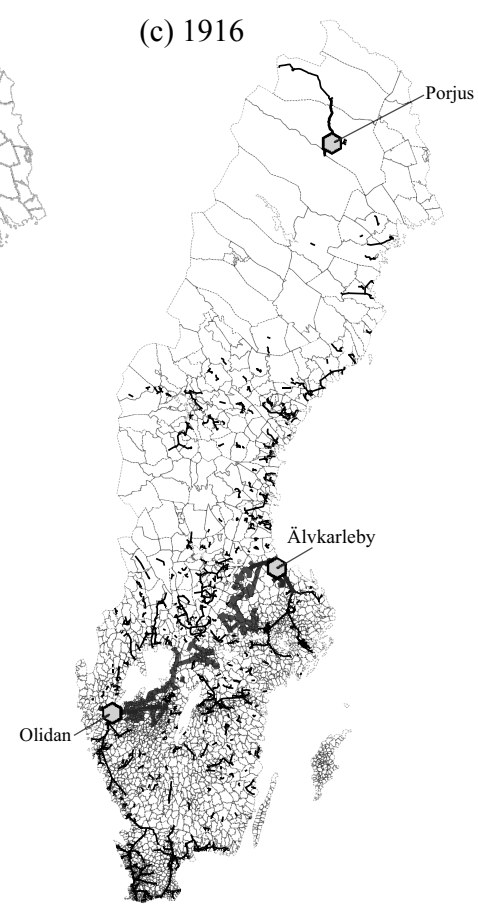

FIGURE 1

EXPANSION OF THE SWEDISH ELECTRICITY GRID, 1906-1916

Notes: This figure shows the expansion of the Swedish electricity grid between 1906 and 1916. Markers denote the three state-run hydropower plants, Olidan, Älvkarleby, and Porjus. The thick lines denote the Western Line, which was constructed to connect Olidan and Älvkarleby.

Sources: Digitized survey maps, Swedish National Archives, Riksarkivet.

the location of power plants and the explicit intention to connect Olidan and Älvkarleby via a state-sponsored mainline system, the Western Line, we consider parishes connected to the first mainline and within a 60-kilometer buffer along a straight line between the two plants as our main treatment variable. The sample from the Western Line consists of 192 parishes and is depicted with thick lines in Figure 1.

\section{Regression Framework}

The panel data structure allows a difference-in-difference interpretation of the estimates. Our regression specification takes the form

$$
y_{i, t}=\alpha+\beta_{1} \text { WesternLine }_{i, t}+\text { Controls }_{i, t}+\mu_{i}+\lambda_{t}+\theta_{j, t}+\varepsilon_{i, t},
$$

where $y_{i, t}$ is the logarithm of $1+$ the outcome variables, which is then scaled by 100 to simplify the interpretation. The outcome variable 
measures the number of strikes or the share of workers by HISCLASS in parish $i$ at period $t$. For temporal coherence with the survey maps, we aggregate the strike data to cover four years following the benchmark year provided by the digitized map. Thus, $t$ refers to an aggregated period in the years following the benchmark in the dataset with strikes (i.e., 1907-1910, 1912-1915, and 1917-20) or at the census year (1900 and 1910) for the employment structure. ${ }^{15}$ If parish $i$ in period $t$ was connected to the grid on the Western Line, the dummy variable WesternLine takes the value 1 , and 0 otherwise. The main coefficient of interest is $\beta_{1}$. We also construct a control variable that takes the value of 1 if the parish is connected by any other power line and 0 otherwise. Table A1 of Online Appendix A provides descriptive statistics for the variables included in the analysis.

The specification is intended to address the potential endogeneity of electricity adoption by only analyzing the impact of electricity in parishes that were connected to the network through the Western Line, and thus exogenously shocked by this early technical advantage. The idea behind the identification is that the cost of gaining connectivity differed significantly between areas after the construction of the Western Line since the price of access was fundamentally dictated by the distance to the powergenerating source. ${ }^{16}$

Table 2 shows that the parishes that were connected with a power line belonging to the Western Line, on a straight line between Olidan and Älvkarleby, did not enjoy any obvious advantages before the construction of the line. Columns (1) and (2) compare parishes connected along the Western Line with all other parishes in the year 1900, which is prior to the construction of the network. Column (3) shows the mean differences of key variables, with standard errors in parentheses. As seen in the table, the Western Line parishes were similar in terms of the average size of their labor force (638 workers in unconnected versus 651 in the parishes that were connected subsequently). They were also essentially similar in terms of their occupational composition with only two exceptions: the Western Line parishes had a lower share of farmers while having a

\footnotetext{
${ }^{15}$ The aggregation was constructed to pick up the lagged effects of gaining access to electricity and to even out short-term fluctuations. We tried different specifications with regards to aggregating the data, for example, covering census years instead or adding five years following the map. The results are not sensitive to alternative forms of aggregation. Table A6 in Online Appendix B shows, for example, how the results change if a five-year period including the benchmarks was chosen instead.

${ }^{16}$ As an alternative, we have dealt with endogeneity by using the distance to the power plants as an instrumental variable in a two-stage regression predicting electricity adoption. The results from this approach are qualitatively similar to the results in the present paper and can be found in Molinder et al. (2019).
} 
TABLE 2

DIFFERENCES BETWEEN CONNECTED AND UNCONNECTED PARISHES PRIOR TO ACCESS TO THE GRID, 1900

\begin{tabular}{|c|c|c|c|}
\hline & $\begin{array}{c}(1) \\
\text { Western Line }\end{array}$ & $\begin{array}{l}(2) \\
\text { Other }\end{array}$ & $\begin{array}{c}(3) \\
\text { Difference (1) - (2) }\end{array}$ \\
\hline Labor force & $\begin{array}{c}651 \\
(966)\end{array}$ & $\begin{array}{c}635 \\
(2224)\end{array}$ & $\begin{array}{c}16 \\
{[160]}\end{array}$ \\
\hline 1. Elite $(\%)$ & $\begin{array}{c}1.2 \\
(1.1)\end{array}$ & $\begin{array}{c}1.1 \\
(1.0)\end{array}$ & $\begin{array}{c}0.15 \\
{[0.08]}\end{array}$ \\
\hline 2. White collar $(\%)$ & $\begin{array}{c}5.8 \\
(3.6)\end{array}$ & $\begin{array}{c}5.6 \\
(3.7)\end{array}$ & $\begin{array}{c}0.23 \\
{[0.27]}\end{array}$ \\
\hline 3. Foremen $(\%)$ & $\begin{array}{c}1.7 \\
(1.5)\end{array}$ & $\begin{array}{l}1.5 \\
(1.4)\end{array}$ & $\begin{array}{c}0.18 \\
{[0.11]}\end{array}$ \\
\hline 4. Medium skilled (\%) & $\begin{array}{c}7.8 \\
(4.9)\end{array}$ & $\begin{array}{c}7.5 \\
(4.4)\end{array}$ & $\begin{array}{c}0.33 \\
{[0.33]}\end{array}$ \\
\hline 5. Farmers $(\%)$ & $\begin{array}{c}28.8 \\
(14.1)\end{array}$ & $\begin{array}{c}31.6 \\
(14.6)\end{array}$ & $\begin{array}{c}-2.8^{* *} \\
{[1.1]}\end{array}$ \\
\hline 6. Lower skilled (\%) & $\begin{array}{l}11.3 \\
(9.3)\end{array}$ & $\begin{array}{c}9.1 \\
(7.9)\end{array}$ & $\begin{array}{l}2.2^{* *} \\
{[0.6]}\end{array}$ \\
\hline 7. Unskilled (\%) & $\begin{array}{l}43.4 \\
(9.5)\end{array}$ & $\begin{array}{c}43.7 \\
(10.8)\end{array}$ & $\begin{array}{l}-0.3 \\
{[0.8]}\end{array}$ \\
\hline No. of strikes & $\begin{array}{l}0.349 \\
(1.23)\end{array}$ & $\begin{array}{l}0.250 \\
(1.62)\end{array}$ & $\begin{array}{l}0.099 \\
{[0.12]}\end{array}$ \\
\hline No. of offensive strikes & $\begin{array}{l}0.144 \\
(0.67)\end{array}$ & $\begin{array}{l}0.110 \\
(0.66)\end{array}$ & $\begin{array}{c}0.034 \\
{[0.049]}\end{array}$ \\
\hline No. of defensive strikes & $\begin{array}{c}0.036 \\
(0.187)\end{array}$ & $\begin{array}{c}0.033 \\
(0.284)\end{array}$ & $\begin{array}{c}0.003 \\
{[0.020]}\end{array}$ \\
\hline No. of Parishes & 192 & 2,278 & 2,470 \\
\hline
\end{tabular}

Notes: Columns (1) and (2) report mean pre-electricity grid access characteristics and standard deviations (in parentheses) for parishes with and without access to the Western Line electricity grid. Column (3) shows difference-in-means and corresponding standard errors (in parentheses). All the characteristics before access to the electricity grid are measured for the year 1900. Occupational group employment is calculated as a percentage of the total labor force in 1900 . Statistical significance is denoted by: $* * * p<0.001,{ }^{* *} p<0.01,{ }^{*} p<0.05$.

Sources: Enflo and Karlsson (2019), Karlsson (2019), Swedish National Data Service, SND 1088, The Swedish National Archives, Umeå University, and the Minnesota Population Center.

somewhat higher share of low-skilled workers. However, although statistically significant, the differences are relatively small, and we will be able to control for the pre-existing skill structure in our empirical specifications later. Most importantly, the parishes of the Western Line hardly differed from the others in terms of our main variable of interest: strikes per period. While the average number of strikes per parish was 0.25 , the corresponding figure along the Western Line was 0.35 . However, the means are surrounded by large standard deviations (about three to four 
times the average), and the test shows that their difference is not statistically significant.

The time-varying controls are there to wash out any confounding effects of other structural transformations in the parishes. First and foremost, we control for the potential impact of relevant major infrastructures, such as the railway and the impact of electricity outside the scope of the Western Line. By adding controls for the lagged effects of the occupational structure, we also take into account initial differences in employment structure before the arrival of electrification. Parish-fixed effects, $\mu_{i}$, ensure that the variation in the model is restricted to parishes that actually experienced a change in access to the grid, while holding all other non-varying parish-specific effects constant and a full set of time dummies, $\lambda_{t}$, control for common time trends and wash out the overall potentially confounding effects of major events in our period, such as WWI. Region-by-period fixed effects, $\theta_{j t}$, are added by interacting time-dummies with dummies for the 24 Swedish counties to take into account region-specific shocks. Standard errors are clustered at the parish level throughout.

We begin the analysis by estimating the effect of access to the Western Line electricity grid on strikes. The main results are estimated from the regression in Equation (1) and organized into three outcome variables relating to the number of strikes: the total number of strikes, the number of offensive strikes, and the number of defensive strikes. The outcome variable in this respect is a count variable. There are, however, alternative ways of measuring strike activity. A complementary way is to look at how electricity affected the number of workers going on strike. Even though we are not able to separate the number of striking workers involved in offensive strikes from those involved in defensive strikes, such an alternative measurement can indicate something about the relative increase in the strength of the protests and complements our main measure. The data in this case, however, are only available for the 1906-1920 period.

We continue the analysis by pinning down how much electrification contributed to labor demand and structural change. We estimate the regression explained in Equation (1) but replace the strike outcomes with the total labor force and the share of the population engaged in agriculture, respectively. These measures are intended to give an indication of how electrification affected structural change and the demand for labor. To analyze labor demand more thoroughly, we also estimate the impact of electricity on occupational change following the HISCLASS census titles. Finally, we investigate whether the relation between electricity and strikes differs between sectors. 


\section{RESULTS}

\section{How Electrification Influenced Strikes}

The impact of electricity on strikes is presented in Table 3 . The top line of Column (1) suggests that access to the Western Line electricity grid increased strike activity by about 11 percent. This increase is substantial, given the fact that the average number of strikes per parish in the period around 1900 was 0.3 , as indicated in Table 2. Parishes on the Western Line were, thus, more likely to see protests increase in the years after they got connected, despite being similar to other parishes prior to electrification.

The observed connection between electricity and strikes would make it tempting to draw the conclusion that the arrival of electricity was followed by a wave of protests against new technology. Looking at the offensive and defensive strikes separately, however, tells a different story. Column (2) in the table shows that the lion's share of the increase comes from offensive strikes, with the point estimate suggesting an almost 10 percent increase. If workers were trying to block or protest the new technology, we would rather expect most of the increase to be in the category labeled as defensive. The effect on defensive strikes is shown in Column (3) and is much more modest than the impact on offensive conflicts, suggesting an increase of only 3 percent following electrification. While Columns (1)-(3) show the estimated impact of electricity on the number of strikes, the effect presented in Column (4) suggests that the number of striking workers increased as well; in this case, by some 42 percent.

Most of the control variables in the regression are not significantly linked to higher strike activity. In part, this is explained by the fact that parish-, time-, and region-by-time fixed effects pick up a lot of unaccounted variation. There is, for example, no estimated effect on strikes from other forms of infrastructure, such as non-Western Line electricity or access to a railroad. However, the impact of the labor force in the preceding period has a positive effect, especially for total and offensive strikes, suggesting that such strikes were more common in faster growing parishes, all other things being equal. The controls for occupational employment shares are in almost all cases not statistically significant. This is not surprising, given that we only use within-parish variation to identify the impact of access to the Western Line electricity grid.

Our specification is designed to allow a causal interpretation from electricity to strikes, but there might still be a worry that the relation is determined by some other underlying factor not properly controlled for 
TABLE 3

MAIN RESULTS

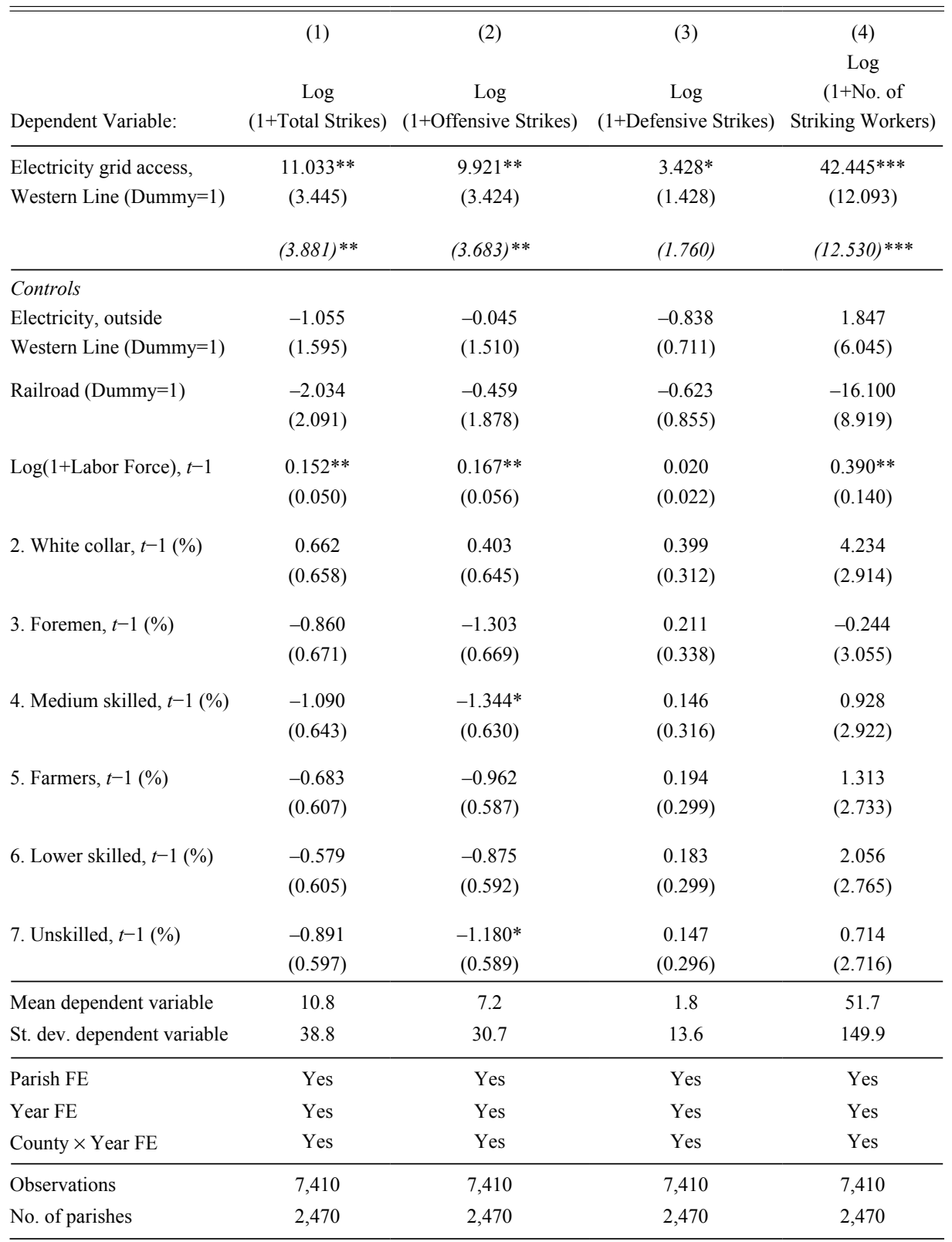

Notes: This table shows the results of estimating the effect of access to the Western Line electricity grid using Equation (1) for the four main outcome variables: total strikes, offensive strikes, defensive strikes, and the number of striking workers. Robust standard errors clustered at the parish level are given in parentheses. ${ }^{* * *} p<0.001,{ }^{* *} p$ $<0.01,{ }^{*} p<0.05$. Standard errors adjusted for spatial autocorrelation in italics, computed using Conley's method assuming linear decay and cut off at $100 \mathrm{~km}$.

Sources: Enflo and Karlsson (2019), Karlsson (2019), Swedish National Data Service, SND 1088, The Swedish National Archives, Umeå University, and the Minnesota Population Center. 


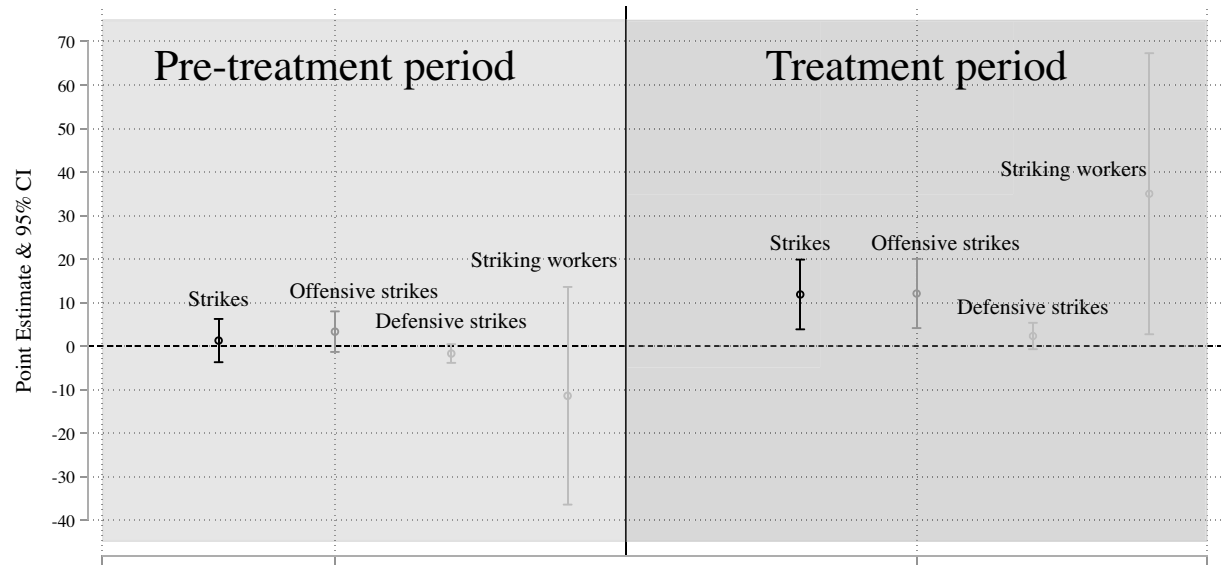

FIGURE 2

EFFECT OF ACCESS TO ELECTRICITY GRID ON STRIKES IN THE TREATMENT AND PRE-TREATMENT PERIODS

Notes: This figure shows point estimates and 95 percent confidence intervals for the impact of access to the Western Line electricity grid in the treatment and pre-treatment periods for the four main outcome variables: total number of strikes, offensive strikes, defensive strikes, and the number of striking workers. The full regression results can be found in Table A2 in Online Appendix A. Sources: Enflo and Karlsson (2019), Karlsson (2019), and Swedish National Data Service, SND 1088, The Swedish National Archives, Umeå University, and the Minnesota Population Center.

excess point. To rule out this possibility, we test whether the effect on strikes was present already before a parish gained access to the Western Line. To ensure that the pre-trends in strike activity are balanced between parishes, we add a forward lag to the specification in Equation (1). If our assertion that the effect on strikes is indeed related to electricity access and not to pre-existing differences between parishes, we should expect the impact of the forward lag to be insignificant. ${ }^{17}$

Figure 2 shows that there were no pre-existing trends for any of the strike variables in the Western Line parishes. The left-hand side of the figure shows the forward lags of all four outcome variables. Reassuringly, all coefficients shown at the left are close to zero and statistically insignificant, suggesting that strike activity did not differ in the parishes that would later gain access to the grid. The corresponding coefficients for the treatment period after controlling for the forward lag are displayed to the right. They convey that the impact appears solely in the treatment period, thus suggesting an impact running from electricity to strikes.

\footnotetext{
${ }^{17}$ Indeed, coefficients should only turn significant in the treatment period, when the grid was in place. Recall that our $t$ constitutes the benchmark year and the four years following it, hence our pre-treatment effect is the impact in the period prior to access to the network. To match our occupational data, we use 1900-1904 as our pre-treatment period.
} 
Our main specification measures Western Line access as a binary variable that is equal to 1 when a parish is connected to the grid by a line. This specification only measures the impact of electricity relatively crudely. It is clear that factories or farms that are located far from the line but still remain inside of a treated parish are probably unaffected by the potential for the new technology, meaning that part of the variation of the outcome comes from units that were not properly exposed to the treatment. In theory, this caveat would bias our results downward, but to really pin down the micro-level effects, we would need more fine-grained data. Unfortunately, we are not able to collect specific electricity rates for individual firms and factories for this period. We can, however, try to address this issue by varying the strength of the treatment by taking the relative electricity exposure by parish into account. This means replacing the binary electricity variable with two alternative measures: (1) the number of power lines in a parish and (2) the total length of the power lines inside the parish. The results of this check are found in Table 4, where we can see that the estimated coefficients in this alternative specification are qualitatively similar to the main regression in Table 3 . While the top row indicates that each additional line increases the number of strikes by about 13 percent, the bottom row suggests that a percentage increase in the total length of the lines of the Western Line grid within the parish increases strikes by about 1.5 percent. In both cases, the increase is larger for offensive strikes than for defensive. Similarly, an additional line increases the number of striking workers by some 40 percent, and each percentage point growth of the grid lines increases it by about 5 percent. These alternative estimates confirm the suspicion that the binary variable is biasing our estimates downward by not fully picking up the true impact of electrification.

Another concern relates to the potentially direct effects on local demand stemming from the construction of the large hydro-plants. Previous studies have demonstrated that early electricity investment stimulated local economies and generated spillovers in terms of a general increase in demand. Studies from the United States have indicated large gains in employment and growth effects from early infrastructure investments, such as electricity generating dams and grid lines (Kline and Moretti 2013). Thus, economies of agglomeration could appear in early developing regions, especially if electricity investments were accompanied by complementary infrastructure investments that signaled a general faith in the region and helped to coordinate expectations and fuel a surge in 
TABLE 4

ALTERNATIVE MEASUREMENT OF TREATMENT

\begin{tabular}{|c|c|c|c|c|}
\hline Dependent Variable: & $\begin{array}{c}(1) \\
\text { Log } \\
(1+\text { Total Strikes) }\end{array}$ & $\begin{array}{c}(2) \\
\text { Log } \\
(1+\text { Offensive Strikes) }\end{array}$ & $\begin{array}{c}\text { (3) } \\
\text { Log } \\
\text { (1+Defensive Strikes) }\end{array}$ & $\begin{array}{c}(4) \\
\text { Log } \\
(1+\text { Striking Workers })\end{array}$ \\
\hline $\begin{array}{l}\log (1+\text { No. of grid lines, } \\
\text { Western line })\end{array}$ & $\begin{array}{c}11.81 * * \\
(4.128) \\
(3.800) * *\end{array}$ & $\begin{array}{l}11.41 * * \\
(4.397) \\
(4.191)^{* *}\end{array}$ & $\begin{array}{c}5.958 * * * \\
(2.017) \\
(2.274) * *\end{array}$ & $\begin{array}{c}42.61 * * * \\
(12.66) \\
(11.46) * * *\end{array}$ \\
\hline $\begin{array}{l}\log (1+\text { Length of grid lines, } \\
\text { Western line })\end{array}$ & $\begin{array}{c}1.389 * * \\
(0.428) \\
(0.462)^{* *}\end{array}$ & $\begin{array}{c}1.274 * * \\
(0.434) \\
(0.442)^{* *}\end{array}$ & $\begin{array}{l}0.493 * * \\
(0.189) \\
(0.223)^{*}\end{array}$ & $\begin{array}{c}5.397 * * * \\
(1.479) \\
(1.532) * * *\end{array}$ \\
\hline $\begin{array}{l}\text { Mean dependent variable } \\
\text { St. dev. dependent variable }\end{array}$ & $\begin{array}{l}10.8 \\
38.8\end{array}$ & $\begin{array}{c}7.2 \\
30.7\end{array}$ & $\begin{array}{c}1.8 \\
13.6\end{array}$ & $\begin{array}{c}51.7 \\
149.9\end{array}$ \\
\hline $\begin{array}{l}\text { Controls } \\
\text { Parish FE } \\
\text { Year FE } \\
\text { County } \times \text { Year FE }\end{array}$ & $\begin{array}{l}\text { Yes } \\
\text { Yes } \\
\text { Yes } \\
\text { Yes }\end{array}$ & $\begin{array}{l}\text { Yes } \\
\text { Yes } \\
\text { Yes } \\
\text { Yes }\end{array}$ & $\begin{array}{l}\text { Yes } \\
\text { Yes } \\
\text { Yes } \\
\text { Yes }\end{array}$ & $\begin{array}{l}\text { Yes } \\
\text { Yes } \\
\text { Yes } \\
\text { Yes }\end{array}$ \\
\hline $\begin{array}{l}\text { Observations } \\
\text { No. of parishes }\end{array}$ & $\begin{array}{l}7,410 \\
2,470\end{array}$ & $\begin{array}{l}7,410 \\
2,470\end{array}$ & $\begin{array}{l}7,410 \\
2,470\end{array}$ & $\begin{array}{l}7,410 \\
2,470\end{array}$ \\
\hline
\end{tabular}

Notes: This table shows the results of estimating the effect of access to the Western Line electricity grid using Equation (1) for the four main outcome variables, using the number of grid lines, and the length of grid lines as alternative measurements of treatment. Robust standard errors clustered at the parish level are given in parentheses. ${ }^{* * *} p<0.001,{ }^{* *} p<0.01,{ }^{*} p<0.05$. Standard errors adjusted for spatial autocorrelation in italics, computed using Conley's method assuming linear decay and cut off at $100 \mathrm{~km}$.

Sources: Enflo and Karlsson (2019), Karlsson (2019), Swedish National Data Service, SND 1088, The Swedish National Archives, Umeå University, and the Minnesota Population Center.

building activities. Such agglomeration economies could potentially be driving strikes for reasons other than technical change due to the arrival of electricity. To rule out the possibility that the impact on strikes was driven by the areas in the direct vicinity of Olidan and Älvkarleby, we exclude all the parishes closest to the power plants and re-run the regressions. ${ }^{18}$ The results are found in Table 5 and are qualitatively similar to the main results. It seems, therefore, that our estimates are picking up the effect of new technology along the entire Western Line grid, and not just in the closest proximity to the large power plants.

In the Online Appendix, we consider two additional robustness checks. First, we run our main regression with weights for a parish population. Second, we run a regression where strikes are measured as a dichotomous dummy variable, assessing the effect of access to the Western Line electricity grid on the chance that any strike took place. The full results can

\footnotetext{
${ }^{18}$ A similar approach to alleviate concerns of direct effects from plant construction on general demand was carried out in Lewis and Severnini (2020).
} 
TABLE 5

EXCLUDING THE PARISHES CLOSEST TO POWER PLANTS

\begin{tabular}{lcccc}
\hline \hline & & & & \\
& $(1)$ & $(2)$ & $(3)$ & $(4)$ \\
Dependent Variable: & Log & Log & Log & Log \\
$(1+$ Total Strikes) & $(1+$ Offensive Strikes $)$ & $(1+$ Defensive Strikes) & Striking Workers) \\
\hline Electricity grid access, & $11.18^{* *}$ & $10.06^{* *}$ & 2.070 & $39.90^{* *}$ \\
Western Line (Dummy=1) & $(3.502)$ & $(3.295$ & $(1.179)$ & $(12.57)$ \\
& $(3.970)^{* *}$ & $(3.657)^{* *}$ & $(1.421)$ & $(12.61)^{* *}$ \\
\hline Mean dependent variable & 10.4 & 6.9 & 1.8 & 50.4 \\
St. dev. dependent variable & 38.0 & 29.9 & 13.3 & 147.6 \\
\hline Controls & Yes & Yes & Yes & Yes \\
Parish FE & Yes & Yes & Yes & Yes \\
Year FE & Yes & Yes & Yes & Yes \\
County $\times$ Year FE & Yes & Yes & Yes & Yes \\
\hline Observations & 7,374 & 7,374 & 7,374 & 7,374 \\
No. of parishes & 2,467 & 2,467 & 2,467 & 2,467 \\
\hline
\end{tabular}

Notes: This table shows the results of estimating the effect of access to the Western Line electricity grid using Equation (1) for the four main outcome variables, excluding parishes with a power plant or bordering a parish with a power plant. Robust standard errors clustered at the parish level are given in parentheses. $* * * p<0.001, * * p<0.01$, ${ }^{*} p<0.05$. Standard errors adjusted for spatial autocorrelation in italics, computed using Conley's method assuming linear decay and cut off at $100 \mathrm{~km}$.

Sources: Enflo and Karlsson (2019), Karlsson (2019), Swedish National Data Service, SND 1088, The Swedish National Archives, Umeå University, and the Minnesota Population Center.

be found in Table A8 and Table A9 of Online Appendix B. In both cases, the results are similar to the ones reported in our main regression. ${ }^{19}$

\section{Mechanisms: Structural and Occupational Change}

We now turn to an analysis of how the Western Line affected structural change and the demand for labor by running the regression in Equation (1) with the log of the labor force and the share of workers in agriculture as outcome variables. Table 6 presents the results. Column (1) suggests that electricity led to an increase in the labor force of about 11 percent..$^{20}$ Consequently, the arrival of electricity did not result in

${ }^{19}$ The effect on total strikes, offensive strikes, and defensive strikes are somewhat larger in the weighted regression: $29.9,42.3$, and 18.4 , respectively. When we measure strikes as a dichotomous variable, the effect on total strikes, offensive strikes, and defensive strikes are 0.083 , 0.059 , and 0.036 , respectively.

${ }^{20}$ The regression in Column (1), estimating the effect of electrification on the size of the labor force, includes the lag of the outcome variable as a control, which affects the interpretation of the estimate. However, the effect of the lag of the dependent variable in this case is very small: only 0.045 , compared to 11.11 for the contemporaneous effect, and not statistically significant. Excluding the lag of the dependent variable from the model also does not noticeably affect the estimate. 
TABLE 6

EFFECT ON LABOR DEMAND AND STRUCTURAL CHANGE

\begin{tabular}{lcc}
\hline \hline Dependent Variable: & $\begin{array}{c}(1) \\
\text { Log(1+Labor Force) }\end{array}$ & $\begin{array}{c}(2) \\
\text { Share of Population in Agriculture (\%) }\end{array}$ \\
\hline Electricity grid access, & $11.11^{* *}$ & $-2.257^{*}$ \\
Western line (Dummy $=1)$ & $(3.566)$ & $(0.992)$ \\
& $(3.361)^{* *}$ & $(0.847)^{* *}$ \\
\hline Mean dependent variable & 586.0 & 48.2 \\
St. dev. dependent variable & 101.9 & 18.7 \\
\hline Controls & Yes & Yes \\
Parish FE & Yes & Yes \\
Year FE & Yes & Yes \\
County $\times$ Year FE & Yes & Yes \\
\hline Observations & 4,934 & 4,934 \\
No. of parishes & 2,470 & 2,470 \\
\hline
\end{tabular}

Notes: This table shows the results of estimating the effect of access to the Western Line electricity grid using Equation (1) for two measures of labor demand and structural change: the size of the labor force and the share of the population in agriculture. Robust standard errors clustered at the parish level are given in parentheses. ${ }^{* *} p<0.001,{ }^{*} p<0.01,{ }^{*} p<0.05$. Standard errors adjusted for spatial autocorrelation in italics, computed using Conley's method assuming linear decay and cut off at $100 \mathrm{~km}$.

Sources: Enflo and Karlsson (2019), Karlsson (2019), Swedish National Data Service, SND 1088, The Swedish National Archives, Umeå University, and the Minnesota Population Center.

overall technological unemployment. But it seems that the composition of jobs changed. In Column (2), the share of the population in agriculture declined by about -2.3 percentage points following electrification. The size of the effect is similar to the fixed-effect estimate by Leknes and Modalsli (2020) of about -4 percentage points for Norway in the early twentieth century and suggests that electrification caused a structural change away from agriculture also in the short run. The results are consistent with the previous literature emphasizing the importance of electrification for rural industrialization in Sweden (Berger, Enflo, and Henning 2012).

To further understand how electricity changed labor market conditions locally, we turn to analyze occupational changes among different skill groups. This time, we estimate the regression with the share of employment in each of the seven HISCLASS-coded occupational groups, and for ease of interpretation, we present the results in a figure. The full regression table is presented in Table A3 in Online Appendix A. The pattern in Figure 3 can at best be described as occupational upgrading. Looking at the three highest skilled groups (the elite, white-collar workers, and foremen) in the figure, we do not detect any sign of electricity being 


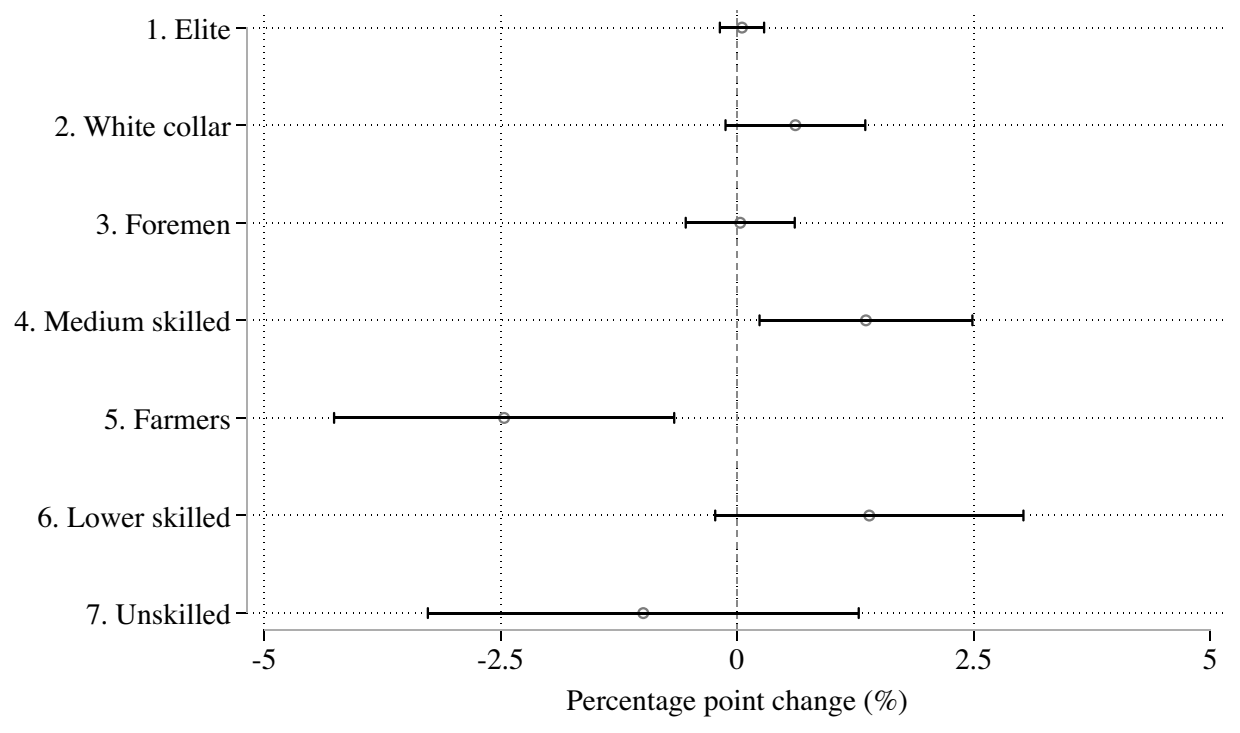

FIGURE 3

REGRESSION RESULTS FOR CHANGE IN OCCUPATIONAL GROUPS' SHARES

Notes: This figure shows point estimates and 95 percent confidence intervals for the impact of a parish gaining access to the Western Line electricity grid on the growth of employment shares by skill group. Standard errors are clustered at the parish level. Full regression results can be found in Table A3 of Online Appendix A. Results for absolute employment growth is available in Figure A2 and Table A11 in Online Appendix B.

Sources: Enflo and Karlsson (2019), Karlsson (2019), and Swedish National Data Service, SND 1088, The Swedish National Archives, Umeå University, and the Minnesota Population Center.

a skill-biased technology. Instead, the increase in employment shares occurred for medium-skilled workers, who saw their proportion increase by about 1.5 percentage points. The decreases in share of employment are concentrated among farmers, again indicating that structural change away from agriculture created new jobs outside this sector. ${ }^{21}$

The results do not directly mirror either the notion of electricity as a skill-biased technology (Goldin and Katz 1998) or as a driver of occupational hollowing out (Gray 2013). Our pattern regarding the impact of electricity can rather be described as "hollowing in," with relative employment growth in medium-skilled occupations. However, it is possible to reconcile our "hollowing in" with the previous results by remembering that the above-mentioned studies focus on the manufacturing sector only. Looking at the American economy in the same period more broadly, Katz and Margo (2014) found neither deskilling nor hollowing out,

${ }^{21}$ The results for absolute employment growth, showing statistically significant increases in the demand for white-collar professionals, medium-skilled workers, and lower-skilled workers, can be found in Figure A2 and Table A11 in Online Appendix B. 
emphasizing that it may not be correct to infer economy-wide patterns of occupational change from those occurring in manufacturing alone.

\section{SECTORAL PATTERNS}

Given the effects on structural change and occupational upgrading presented in the previous section, it is possible that the results for strikes shown in Table 3 are driven by a changing sectoral composition in parishes that gained access to the Western Line electricity grid. Electrification increased the speed of industrialization in the adopting parishes, and since there are differences in the degrees of organization between sectors, as discussed in the historical background and conceptual framework section, the effect could be the composite result of structural change towards sectors with higher strike propensity. Ideally, we would like to separate the within- and between-sector effects by a decomposition of the kind performed in Gray (2013), but we are restricted by the data in two ways: first, we only have access to data on the employment structure until 1910 and, second, we neither know industry nor regionspecific electricity intensities. We can, however, still look at the effects of electricity adoption separately between sectors.

To find out whether electricity had differing impacts on the propensity to strike, we start by running our main regression separating the agricultural sector from the rest of the economy. As shown in Figure 4, there are large differences in the impact when analyzing agriculture separately from the rest of the economy. ${ }^{22}$ While electricity did not generate any significant increase in the number of strikes by agricultural workers, the effects are large and significant outside agriculture. This result could be driven by a larger propensity to go on strikes in the industrial and service sectors, but it still contradicts the idea that the workers losing from structural change are more likely to protest using strikes. Instead, sectors with increasing labor demand are the ones with more conflicts. In addition, the strikes are mainly of an offensive nature, as suggested by the point estimate. It must be noted, however, that the standard errors of the offensive strikes overlap with the standard errors of the defensive strikes, meaning that we cannot statistically distinguish the nature of the causes at conventional levels of statistical precision. Still, differences in strike activity between industry and services suggest that workers in expanding sectors experienced an improved labor market position and could claim the benefits by asking for more from employers.

\footnotetext{
${ }^{22}$ Figure A1 of Online Appendix B shows a further separation between industry and services and indicates that the effects on strikes are similar in the industrial and service sectors.
} 


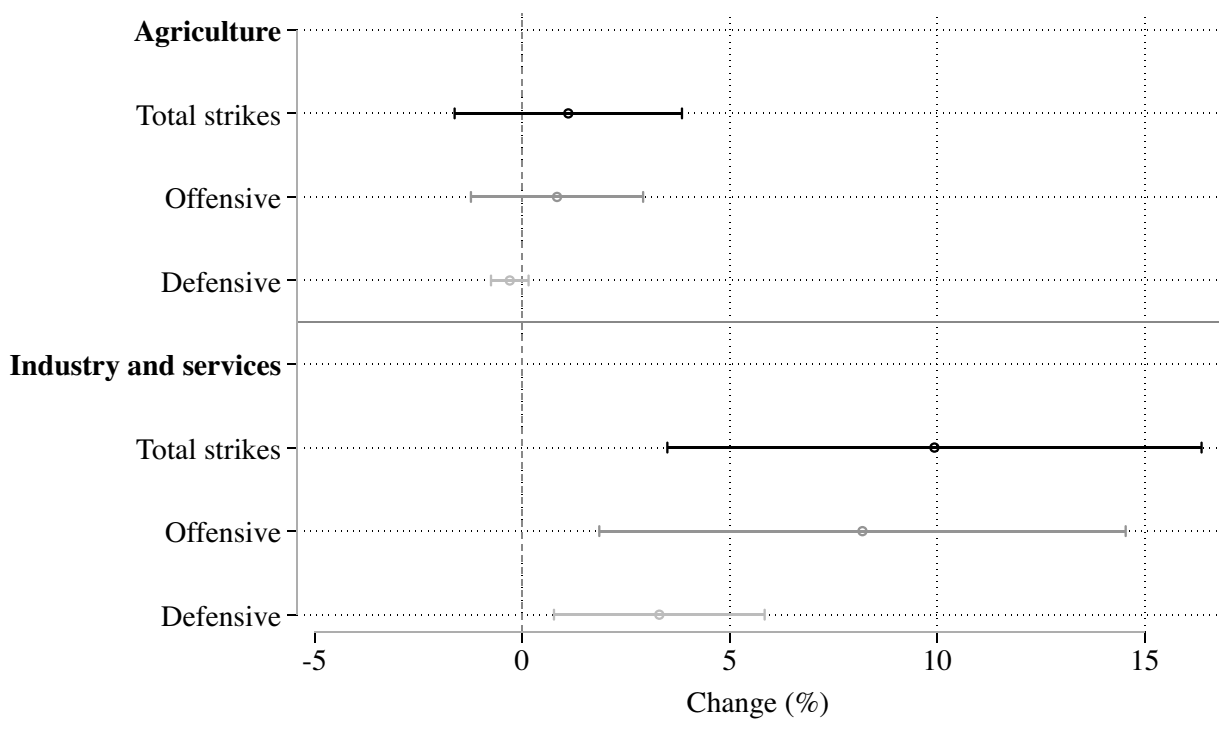

FIGURE 4

REGRESSION RESULTS FOR STRIKES BY SECTOR

Notes: This figure shows point estimates and 95 percent confidence intervals for the impact of a parish gaining access to the Western Line electricity grid on the increase in the number of strikes by sector. Standard errors are clustered at the parish level. The full regression table can be found in Table A4 of Online Appendix A.

Sources: Enflo and Karlsson (2019), Karlsson (2019), and Swedish National Data Service, SND 1088, The Swedish National Archives, Umeå University, and the Minnesota Population Center.

If workers were able to use strikes as a bargaining tool to strengthen their position, we should expect to see more strikes in areas with less scope for alternative sources of labor. To test this idea, we wish to assess whether the impact on strikes is attributable to heterogenous effects in initial sectoral composition. Intuitively, it could be harder for firms to combat strikes by hiring outside labor in regions with higher industrial concentration. Therefore, we would expect already industrial parishes to show up as the most strike-prone with the arrival of electricity. Figure 5 investigates the potential effects by separating the parishes that were initially industrial, in terms of being above the median in the share of manufacturing in total employment in 1900, from other parishes. We run the main regression with strikes as an outcome variable and an interaction between the Western Line dummy and a dummy that is 1 for parishes with above median industrialization in 1900 .

The figure shows the interacted coefficient, a crude measure of the "pure" effect of electrification in parishes that had already gone relatively far in the process of industrialization, suggesting that the effects on strikes are pronounced in the already industrial parishes but non-existent 


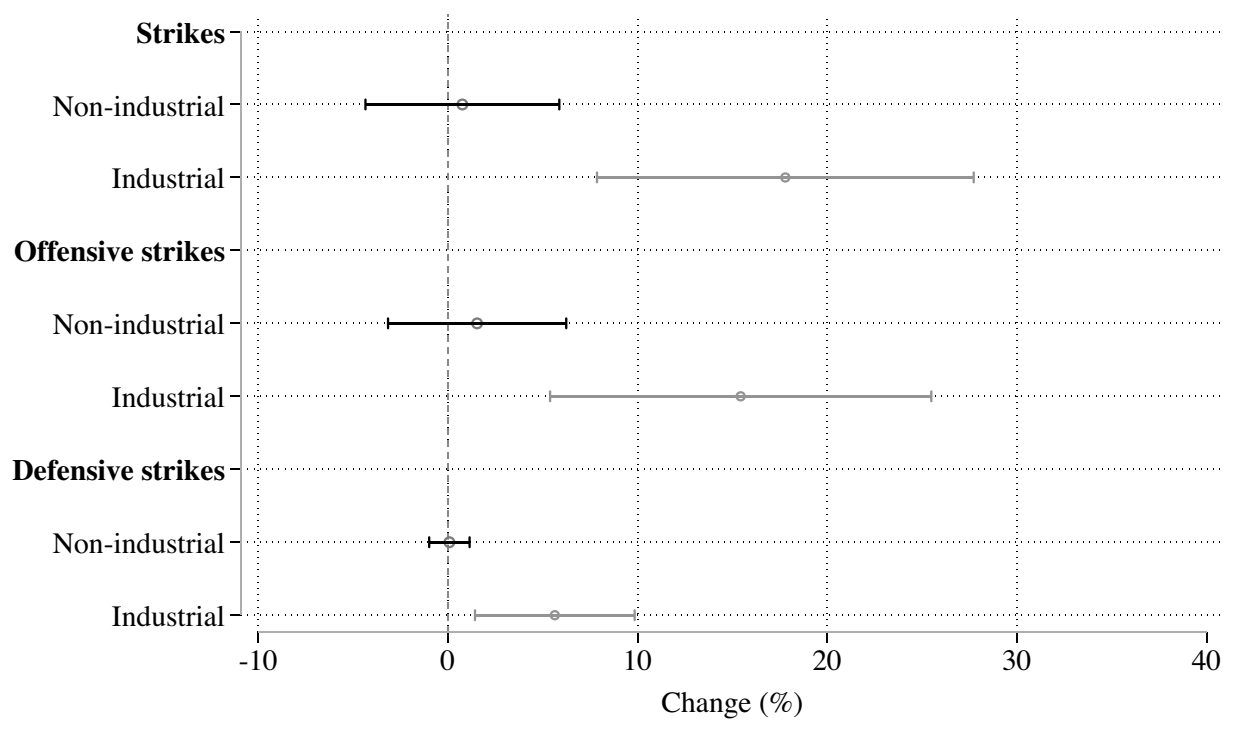

FIGURE 5

RESULTS FOR STRIKES BY TYPE OF PARISH: NON-INDUSTRIAL/INDUSTRIAL

Notes: This figure shows results of interacting Western Line electricity grid access with an indicator for whether a parish is non-industrial or industrial. Industrial parishes are defined as the 50 percent of parishes with the highest share of industry in total employment in 1900. Standard errors clustered at the parish level. The full regression table can be found in Table A5 of Online Appendix A.

Sources: Enflo and Karlsson (2019), Karlsson (2019), and Swedish National Data Service, SND 1088, The Swedish National Archives, Umeå University, and the Minnesota Population Center.

in the others. Again, the effects are larger for offensive strikes. Thus, even when we compare the most industrial parishes with each other, gaining access to electricity is the decisive factor that spurs offensive strikes, not being industrial per se, reinforcing the message that the action is taking place in the expanding sectors in which demand for labor is higher and sources of alternative workers limited. Gaining access to electricity in agricultural parishes, on the other hand, does not increase the propensity of workers to go on strike. ${ }^{23}$

\section{CONCLUSIONS}

We have analyzed the relationship between electrification and strikes in Sweden at the local level, focusing on a period of intense expansion of the

\footnotetext{
${ }^{23}$ To check that industrial parishes are not different in terms of strike capacity due to them being more densely populated or urban, we also ran a regression interacting instead a coefficient that takes the value 1 if the parish was above the median in terms of population density in 1900 . The results are seen in Figure A3 in Online Appendix B. The result indicates that electricity increased strikes in urban and rural parishes alike. We conclude from this that what mattered was their sectoral composition, and not whether they were urban or not.
} 
grid for power distribution. We established an increase in strikes following access to the electricity grid. However, the conflicts caused by electrification were typically not conflicts with the intention of blocking technological development. Actually, conflicts with the openly declared intention to resist mechanization were extremely rare in our dataset. Instead, electrification was more commonly associated with workers demanding higher wages and better working conditions rather than workers defending the status quo. In that sense, the grid did not only bring more motive power to firms but also increased bargaining power to large segments of workers. This is a perspective that has been used to refer to labor conflicts in modern, "post-industrial societies," but more seldom with regard to the formative years of labor movement and labor market institutions in Western societies.

In addition to contributing to the literature on technological change and social unrest, our paper also shed light on changes in the labor demand and skill distribution during the Second Industrial Revolution. Rather than widespread technological unemployment, we find that electrification increased the overall demand for labor and was associated with a shift in demand from unskilled agricultural workers to lower- and mediumskilled manufacturing workers. Instead of leading to vast technological unemployment, electrification spurred structural change. Thus, we do not find evidence of a "hollowing out" of the skill distribution, at least not when looking at the entire structure of the economy.

The connection between grid connectivity and strikes that we establish can easily escape observation since workers did not explicitly relate their demands and actions to electrification. Looking at the past two centuries, it is possible that offensive worker responses to technological change have been more common than defensive protests of the kind seen in the early nineteenth-century riots, although the latter has made a huge imprint in the popular understanding of history. Future research should pay closer attention to the role of unions as strategic actors in the response to technological change and consider how employers responded to the increased bargaining power of specific groups of workers, as well as to the economic consequences of work interruptions.

\section{REFERENCES}

ASEA. Erfarenhetsrön och råd beträffande jordbrukets elektrifiering tillägnade Sveriges jordbrukare, 2nd edition. Stockholm: Allmänna Svenska Elektriska Aktiebolaget, 1912.

Autor, David H., Lawrence F. Katz, and Melissa S. Kearney. "The Polarization of the US Labor Market.” American Economic Review 96, no. 2 (2006): 189-94. 


\section{More Power to the People}

Back, Pär-Erik. En klass i uppbrott: Den fackliga lantarbetarrörelsens uppkomst och utveckling. Malmö, Sweden: Framtiden, 1961.

Berger, Thor, Kerstin Enflo, and Martin Henning. "Geographical Location and Urbanisation of the Swedish Manufacturing Industry, 1900-1960: Evidence from a New Database." Scandinavian Economic History Review 60, no. 3 (2012): 290-308.

Berggren, Lars. Angvisslans och brickornas värld. Om arbete och facklig organisering vid Kockums mekaniska verkstad och Carl Lunds fabrik i Malmö 1840-1905. Ph.D. diss., Lunds universitet, 1991.

Caprettini, Bruno, and Hans-Joachim Voth. "Rage against the Machines: Labor-Saving Technology and Unrest in Industrializing England." American Economic Review: Insights 2, no. 3 (2020): 305-20.

Card, David, and Craig A. Olson. "Bargaining Power, Strike Durations, and Wage Outcomes: An Analysis of Strikes in the 1880s." Journal of Labor Economics 13, no. 1 (1995): 32-61.

Cederqvist, Jane. Arbetare i strejk: Studier rörande arbetarnas politiska mobilisering under industrialismens genombrott: Stockholm 1850-1909. Ph.D. diss., Stockholm: LiberFörlag, 1980.

Dal Bo, Ernesto, Frederico Finan, Olle Folke, Johanna Rickne, and Torsten Persson. Economic Losers and Political Winners: The Rise of the Radical Right in Sweden. Technical Report, Uppsala University, 2017.

Devine, Warren D. "From Shafts to Wires: Historical Perspective on Electrification." Journal of Economic History 43, no. 2 (1983): 347-72.

Drago, Robert, and Wooden, Mark (1990). "The Determinants of Strikes in Australia." Journal of Industrial Relations 32, no. 1 (1990): 32-52.

Edvinsson, Rodney. Growth, Accumulation, Crisis: With New Macroeconomic Data for Sweden 1800-2000. Ph.D. diss., Stockholm: Stockholms universitet, 2005.

Elmquist, Henning. Undersökning af den mekaniska verkstadsindustrien i Sverige. 1, Större egentliga mekaniska verkstäder. Stockholm: K. L. Beckmans Boktryckeri, 1901.

Enflo, Kerstin, and Tobias Karlsson. "From Conflict to Compromise: The Importance of Mediation in Swedish Work Stoppages 1907-1927." European Review of Economic History 23, no. 3 (2019): 268-98.

Fishback, Price. "An Alternative View of Violence in Labor Disputes in the Early 1900s: The Bituminous Coal Industry, 1890-1930." Labor History 36, no. 3 (1995): 426-56.

Franzosi, Roberto. "One Hundred Years of Strike Statistics: Methodological and Theoretical Issues in Quantitative Strike Research.” ILR Review 42, no. 3 (1989): 348-62.

Frey, Carl B. The Technology Trap: Capital, Labor, and Power in the Age of Automation. Princeton, NJ: Princeton University Press, 2019.

Frey, Carl B., Thor Berger, and Chinchih Chen. (2017). Political machinery: Automation anxiety and the 2016 US presidential election. Technical report, Oxford Martin School Working Paper, University of Oxford, UK. Available at https:// www.oxfordmartin.ox.ac.uk/downloads/academic/Political\%20MachineryAutomation\%20Anxiety\%20and\%20the\%202016\%20U_S_\%20Presidential\%20 Election_230712.pdf. 
Frey, Carl B., and Michael A. Osborne. "The Future of Employment: How Susceptible Are Jobs to Computerisation?" Technological Forecasting and Social Change 114 (2017): 254-80.

Gaggl, Paul, Rowena Gray, Ionana Marinescu, and Miguel Morin. "Does Electricity Drive Structural Transformation? Evidence from the United States." NBER Working Paper No. 26477, Cambridge, MA, November 2019.

Geraghty, Thomas M., and Thomas Wiseman. "Conflict and Compromise: Changes in US Strike Outcomes, 1880 to 1945." Explorations in Economic History 48, no. 4 (2011): 519-37.

Goldin, Claudia, and Lawrence F. Katz. "The Origins of Technology-Skill Complementarity." Quarterly Journal of Economics 113, no. 3 (1998): 693-732.

Goos, Maarten, and Alan Manning. "Lousy and Lovely Jobs: The Rising Polarization of Work in Britain." Review of Economics and Statistics 89, no. 1 (2007): 118 33.

Gray, Rowena. "Taking Technology to Task: The Skill Content of Technological Change in Early Twentieth Century United States." Explorations in Economic History 50, no. 3 (2013): 351-67.

Hamark, Jesper. "Strikingly Indifferent: The Myth of Militancy on the Docks Prior to World War II." Labor History 54, no. 3 (2013): 271-85.

Hjulström, Filip. Sveriges elektrifiering: En ekonomisk-geografisk studie över den elektriska energiförsörjningens utveckling. Uppsala: Lundequistska Bokhandeln, 1940.

Houpt, Stefan O., and Juan C. R. Cagigal. "Relative Deprivation and Labour Conflict during Spain's Industrialization: The Bilbao Estuary, 1914-1936." Cliometrica 8, no. 3 (2014): 335-69.

Huberman, Michael, and Denise Young. "Hope against Hope: Strike Activity in Canada, 1920-1939." Explorations in Economic History 39, no. 3 (2002): 315-54.

Johansson, Mats. Mörekonflikten: Klassformering, agrar kapitalism och klasskonflikt $i$ Södra och Norra Möre härader 1929-1931. Växjö: Växjö universitet, 2008.

Kander, Astrid. Economic Growth, Energy Consumption and CO2 Emissions in Sweden 1800-2000. Lund, Sweden: Lund University, 2002.

Karlbom, Rolf. Hungerupplopp och strejker 1793-1867: En studie $i$ den svenska arbetarrörelsens uppkomst. Lund: Gleerup, 1967.

Karlsson, Tobias. "Strikes and Lockouts in Sweden: Reconsidering Raphael's List of Work Stoppages 1859-1902.” Lund Papers in Economic History, Paper No. 192. Lund, Sweden, 2019.

Katz, Lawrence F., and Robert A. Margo. "Technical Change and the Relative Demand for Skilled Labor: The United States in Historical Perspective.” In Human Capital in History: The American Record, edited by Leah Platt Boustan, Carola Fryman, and Robert A. Margo, 15-57. Chicago: University of Chicago Press, 2014.

Kitchens, Carl, and Price Fishback. "Flip the Switch: The Impact of the Rural Electrification Administration 1935-1940." Journal of Economic History 75, no. 4 (2015): 1161-95.

Kjellberg, Anders. "Facklig organisering i tolv länder [Trade Union Organisation in Twelve Countries]." Ph.D. diss., Lund University, 1983.

Kline, Patrick, and Enrico Moretti. "Local Economic Development, Agglomeration Economies, and the Big Push: 100 Years of Evidence from the Tennessee Valley Authority." Quarterly Journal of Economics 129, no. 1 (2013): 275-331. 


\section{More Power to the People}

Leknes, Stefan, and Jørgen Modalsli. "Who Benefited from Industrialization? The Local Effects of Hydropower Technology Adoption." Journal of Economic History 80, no. 1 (2020): 207-45.

Lewis, Joshua, and Edson Severnini. (2020). "Short-and Long-Run Impacts of Rural Electrification: Evidence from the Historical Rollout of the U.S. Power Grid." Journal of Development Economics 143: Article 102412.

Ljungberg, Jonas. Priser och marknadskrafter i Sverige 1885-1969: En prishistorisk studie. (Diss.). Ph.D. thesis. Lund, Sweden: Lunds universitet, 1990.

Lundh, Christer. Spelets regler: Institutioner och lönebildning på den svenska arbetsmarknaden 1850-2018. Lund: Studentlitteratur, third edition, 2020.

Magnusson, Lars. Arbetet vid en svensk verkstad: Munktells 1900-1920. Lund, Sweden: Arkiv förlag, 1987.

Mikkelsen, Flemming. Arbejdskonflikter i Skandinavien 1848-1980. Odense, Denmark: Odense universitetsforlag, 1992.

Minnesota Population Center. Integrated Public Use Microdata Series, International: Version 7.2 [dataset], 2019. https://doi.org/10.18128/D020.V7.2.

Mokyr, Joel. "Technological Inertia in Economic History." Journal of Economic History 52, no. 2 (1992): 325-38.

Mokyr, Joel, Chris Vickers, and Nicolas L. Ziebarth. "The History of Technological Anxiety and the Future of Economic Growth: Is This Time Different?" Journal of Economic Perspectives 29, no. 3 (2015): 31-50.

Molinder, Jakob, Kerstin Enflo, and Tobias Karlsson. "The Power Resource Theory Revisited: What Explains the Decline in Industrial Conflicts in Sweden?" CEPR Discussion Papers No. 13130, London, England, August 2018.

Molinder, Jakob, Tobias Karlsson, Kerstin Enflo. More Power to the People: Electricity Adoption, Technological Change and Social Conflict. Centre for Economic Policy Research, London, UK, 2019.

—. "Replication: More Power to the People: Electricity Adoption, Technological Change and Labor Conflict." Ann Arbor, MI: Inter-university Consortium for Political and Social Research [distributor], 2020-10-27. https://doi.org/10.3886/ E125281V1.

Morell, Mats. Det svenska jordbrukets historia. Bd 4, Jordbruket i industrisamhället: 1870-1945. Stockholm: Natur och kultur/LT, 2001.

Norgren, Lennart. "Svenska verkstäders elektrifiering: Spridning av elektriska motorer 1896-1916." Historisk Tidskrift 112 (1992): 195-209.

Olsson, Ulf. Regionala löneskillnader inom svensk verkstadsindustri 1913-1963. Göteborg: Göteborgs universitet, 1979.

Perrone, Luca. "Positional Power, Strikes and Wages." American Sociological Review 49, no. 3 (1984): 412-426.

Prado, Svante, and Dimitrios Theodoridis. "Electricity and the Technology-Skill Complementarity: Evidence from the Swedish Industrial Census of 1931." Essays in Economic \& Business History 35, no. 1 (2017): 97-122.

Rationaliseringsutredningen. Rationaliseringsutredningens betänkande D. 1 Motiv och förslag. Stockholm, Sweden, 1939.

Schiller, Bernt. Storstrejken 1909: Förhistoria och orsaker. Malmö, Sweden: Akademiförlaget, 1967.

Schön, Lennart. An Economic History of Modern Sweden. London: Routledge, 2012. 
Shorter, Edward, and Charles Tilly. Strikes in France 1830-1968. Cambridge, UK: Cambridge University Press, 1974.

Stymne, Per. Stamnätet under ett sekel: Berättelsen om hur det svenska stamnätet byggdes upp: En bok till Svenska kraftnäts tioårsjubileum 2002. Sundbyberg, Sweden: Svenska kraftnät, 2002.

The Swedish National Archives, Umeå University, and the Minnesota Population Center. National Sample of the 1890 Census of Sweden, Version 2.0. Minneapolis: Minnesota Population Center [distributor], 2011 a.

- National Sample of the 1900 Census of Sweden, Version 3.0. Minneapolis: Minnesota Population Center [distributor], 2011b.

- National Sample of the 1910 Census of Sweden, Version 1.0. Minneapolis: Minnesota Population Center [distributor], 2016.

Swenson, Peter. A. Capitalists against Markets: The Making of Labor Markets and Welfare States in the United States and Sweden. New York: Oxford University Press, 2002.

van Leeuwen, Marco H. D., and Ineke Maas. HISCLASS: A Historical International Social Class Scheme. Leuven, Belgium: Leuven University Press, 2011.

van Leeuwen, Marco H. D., Ineke Maas, and Andrew Miles. HISCO: Historical International Standard Classification of Occupations. Leuven, Belgium: Leuven University Press, 2002.

Åmark, Klas. Facklig makt och fackligt medlemskap: De svenska fackförbundens medlemsutveckling 1890-1940. Lund, Sweden: Arkiv förlag, 1986. . Solidaritetens gränser: LO och industriförbundsfrågan 1900-1990. Stockholm, Sweden: Atlas, 1998. 